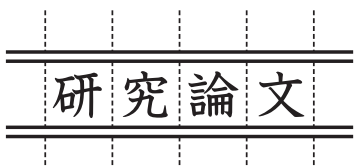

\title{
半導体チップ上への $\mathrm{Al} / \mathrm{Cu}$ クラッドリード端子の直接超音波接合技術の開発 \\ Development of Direct Al/Cu Lead Terminal Ultrasonic Bonding Technology for Power Semiconductor Chips
}

\author{
坂元創一*・米田 裕* ・柳本辰則**・藤野純 司*・菊池正雄 ${ }^{*}$ \\ Soichi SAKAMOTO, Yutaka YONEDA, Tatsunori YANAGIMOTO, Junji FUJINO and Masao KIKUCHI
}

(Received April 20 2015)

\begin{abstract}
Recently, power modules have become widespread because the need for energy-saving technology is increasing. Using wiring technology in place of Al wire for power semiconductor chips has attracted attention along with the progress made in miniaturizing the modules. We investigated a wiring technology for direct ultrasonic bonding $\mathrm{Al} / \mathrm{Cu}$ lead terminals on semiconductor chips. As shown in the results, chip tilt after die-bonding led to reducing the bonding quality. Regardless of the tilt, a large bonding region was obtained by using $\mathrm{Al} / \mathrm{Cu}$ lead terminals with bumps. In addition, a thermal cycle test was conducted for 1000 cycles between $-45^{\circ} \mathrm{C}$ and $150^{\circ} \mathrm{C}$. It was found that tne $\mathrm{Al} / \mathrm{Cu}$ lead terminals with bumps maintained ample bonding area even after rigorous reliability test.
\end{abstract}

Key Words: Ultrasonic Bonding, Power Semiconductor Chips, Al/Cu Lead Terminal, Chip Tilt, Clad Materials

\section{1. 緒言}

近年、環境問題への意識が高まってきており、風力、水力、 太陽光といった自然エネルギーを用いた発電技術や、発電 した電力を効率的に利用するための省エネ技術の必要性が 高まっている。そのキーパーツであるパワーモジュールの 小型化やコストダウンを目的に半導体チップのさらなる縮 小化が進められている。しかしながら、チップの縮小化に より配線スペースが減少し、従来の配線技術である $\mathrm{Al}$ ワイ ヤボンドでは通電容量が小さく、配線に必要な面積を確保 できなくなってきている ${ }^{1)}$ 。そこで、Al ワイヤに代わる通 電容量の大きな半導体チップ上配線技術として、Alリボン 接続、 $\mathrm{Cu}$ ワイヤ接続などの新たなチップ上配線技術が注目 されている ${ }^{2), 3)}$

さらに通電容量の大きな接続方法として、Fig.1に示す

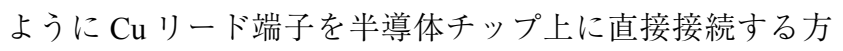

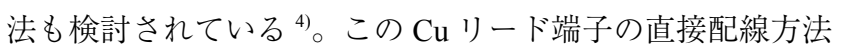
は、小さい面積でも大電流に対応可能であり、また、通電 時のチップ内温度分布の均一化によるパワーサイクル $(\mathrm{P} / \mathrm{C})$ 信頼性の向上といったメリットを有する。特に超音波接合

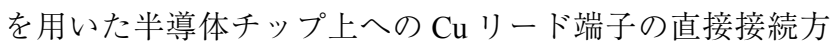
法は、短時間での配線が可能、はんだ接合方法と比較して $\mathrm{Au} / \mathrm{Ni}$ などのチップ上の電極メタライズが不要といったメ
リットが期待される。しかしながら、はんだ接合のような 部材間に接合層が形成される接合方法とは異なり、超音波 接合方法は部材同士を直接接合させるため、被接合部材で ある半導体チップへのダメージや、チップの表面状態およ び、表面形状による接合品質への影響が懸念される。半導 体チップへのダメージ軽減に関しては、半導体チップと $\mathrm{Cu}$ リード端子間に $\mathrm{Al}$ 緩衝層を挟み込むことで半導体チップヘ のダメージを軽減し直接接合可能であることが報告されて Wる ${ }^{4)}$ 。

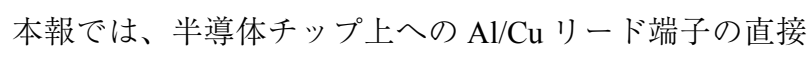

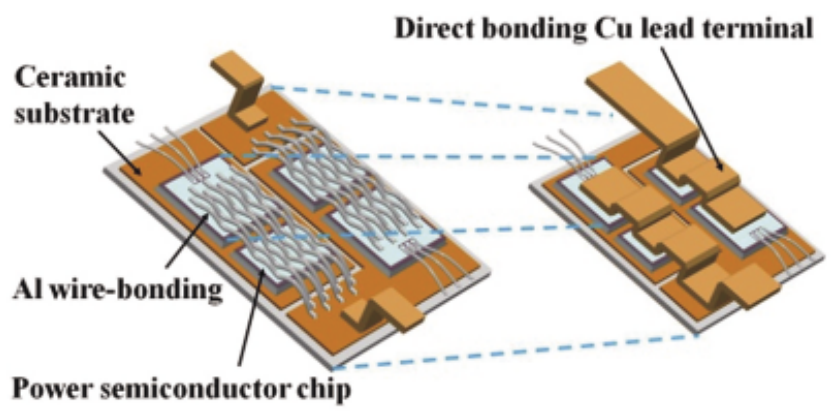

Fig.1 Schematic images of conventional Al wire-bonding package and direct $\mathrm{Cu}$ lead terminal bonding package.

*三菱電機(株) 生産技術センター（† 661-8661 兵庫県尼崎市塚口本町 8-1-1）

Manufacturing Engineering Center, Mitsubishi Electric Corporation (8-1-1 Tsukaguchi-honmachi, Amagasaki, Hyogo, 661-8661 Japan) **三菱電機株)パワーデバイス製作所（† 819-0161 福岡県福岡市西区今宿東 1-1-1）

Power Device Works, Mitsubishi Electric Corporation (1-1-1 Imajukuhigashi, Nishi, Fukuoka, Fukuoka 819-0161 Japan) 


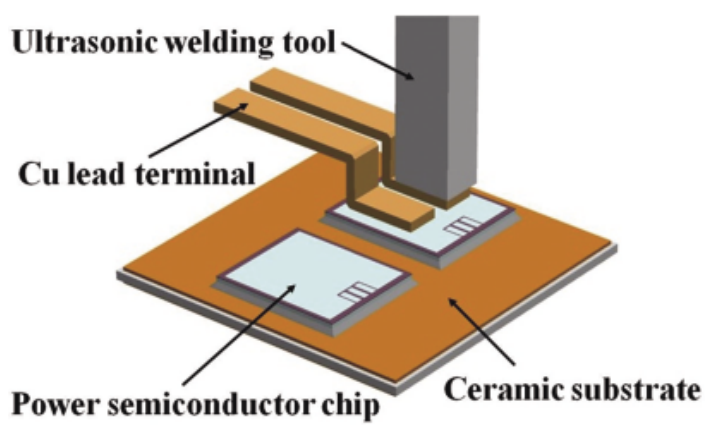

Fig.2 Schematic illustration of direct $\mathrm{Cu}$ lead terminal bonding with ultrasonic bonding.

超音波接合に扔いて、接合品質の中でも特に通電容量、放 熱性に大きく関わる接合面積に着目し、チップ傾きによる

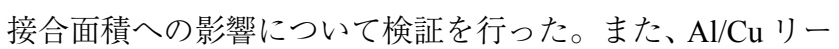
ド端子の $\mathrm{Al}$ 層側にバンプを形成し、チップ傾きへの対策効 果の検証拈よび、信頼性評価を実施した。

\section{2. 実験方法}

\section{1 供試材}

供試材として、Fig.2に示すような $\mathrm{Cu}$ パターン（厚さ $0.25 \mathrm{~mm})$ を積層した AlN 基板 $(61.0 \mathrm{~mm} \times 39.0 \mathrm{~mm}$ 、厚さ $1.14 \mathrm{~mm})$ 上に、鉛フリーはんだ $(\mathrm{Sn}-3.0 \mathrm{Ag}-0.5 \mathrm{Cu} 、 13 \mathrm{~mm}$ $\times 10.5 \mathrm{~mm}$ 、厚さ $0.1 \mathrm{~mm})$ を用いて $\mathrm{Si}$ 半導体チップ (13 $\mathrm{mm} \times 10.5 \mathrm{~mm}$ 、厚さ $0.26 \mathrm{~mm}$ ) をダイボンドしたサンプル を用いた。また、半導体チップ傾きの影響を調査するため に、様々な傾きを有するサンプルを作製した（半導体チッ プ傾き：数 $\mu \mathrm{m}$ 約 $200 \mu \mathrm{m})$ 。半導体チップの傾きについ ては、高精度非接触段差測定機にてダイボンド後のチップ 四隅の高さを測定し、2つの対角高さ差分の大きい方をチッ プ傾きとした。本評価で作製したチップ傾きは、はんだ厚 さやはんだ付けプロセスにもよるが、通常のはんだ付け時 に発生し得る範囲の大きさである。半導体チップ上に直接 超音波接合する評価用リード端子は、 $\mathrm{Cu}$ 板（長さ $40 \mathrm{~mm}$ 、 幅 $4 \mathrm{~mm}$ 、厚さ $0.5 \mathrm{~mm}$ ) および、Fig.3(a) に示した $\mathrm{Al} / \mathrm{Cu}$ クラッド材（長さ $40 \mathrm{~mm}$ 、幅 $4 \mathrm{~mm}$ 、厚さ $0.5 \mathrm{~mm} 、 \mathrm{Al}$ 層： $0.2 \mathrm{~mm} 、 \mathrm{Cu}$ 層：0.3 mm）をパワーモジュールに打けるリー ド端子を模擬して曲げ加工によって作製した。また、作製

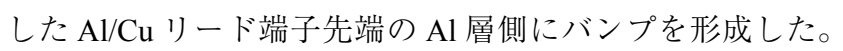
Fig.3(b) に示すように、 $\phi 1.0 \mathrm{~mm}$ 、高さ $0.1 \mathrm{~mm}$ のサイズの バンプを中心および、四隅に各 1 点ずつ、計 5 点のバンプ を形成した。上記のバンプを形成したリード端子を今後、 バンプ $\mathrm{Al} / \mathrm{Cu}$ リード端子と呼ぶこととする。

\section{2 超音波接合方法}

超音波接合時のプロセスを Fig.4に示す。AlN 基板にダ

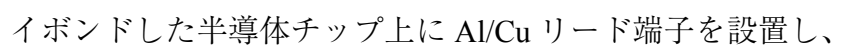
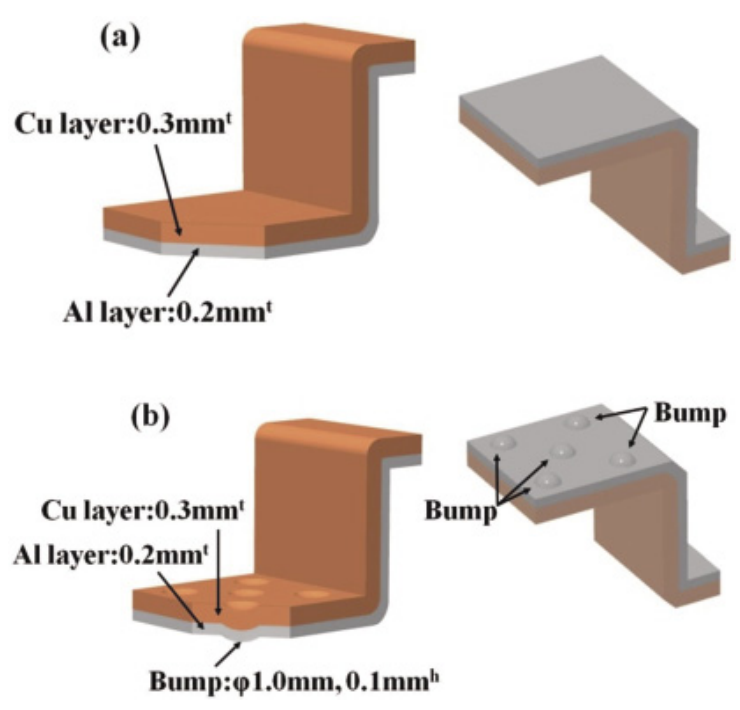

Fig.3 Images of $\mathrm{Al} / \mathrm{Cu}$ lead terminal.

(a) $\mathrm{Al} / \mathrm{Cu}$ lead terminal, (b) Bumped $\mathrm{Al} / \mathrm{Cu}$ lead terminal.

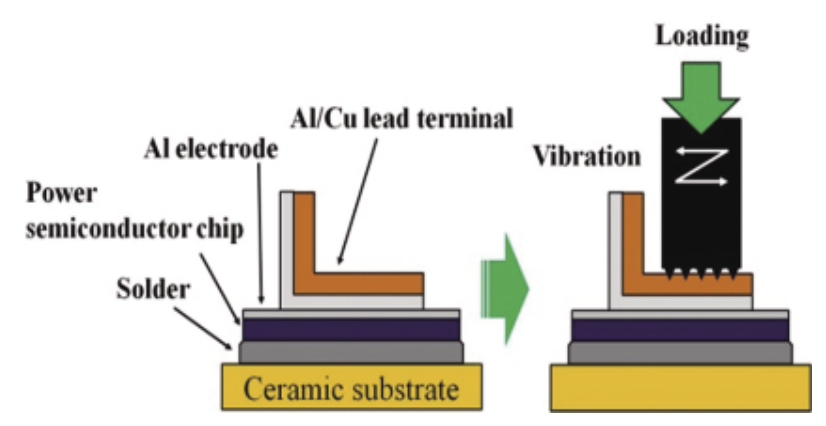

Fig.4 Schematic illustration of ultrasonic bonding process.

周波数 $30 \mathrm{kHz} も し く は 、 40 \mathrm{kHz}$ のホーンを用いて、荷重 と接合時間をパラメータとして超音波接合を行った。また、 本評価で用いた振幅条件は $14.5 \mu \mathrm{m}$ もくは、 $15.2 \mu \mathrm{m}$ であ る。接合状態を確認するために、超音波接合後、サンプル の裏面より SAT（Scanning Acoustic Tomograph：超音波探傷 装置）観察を行った。また、画像処理ソフトを用いて観察 したSAT 画像の二值化を行い、接合面積を求めた。

\section{3 温度サイクル試験}

供試材として、AIN 基板上にダイボンドした $\mathrm{Si}$ 半導体チッ

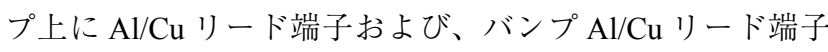
を直接超音波接合したサンプルを用いた。この時、超音波 接合条件は、振幅：15.2 $\mu \mathrm{m}$ 、荷重：200 N、時間：0.2 s で ある。

作製したサンプルを温度サイクル試験機に投入した。温 度サイクルの条件は、 $-45^{\circ} \mathrm{C} \sim 150^{\circ} \mathrm{C} 、 20 \mathrm{~min} / 20 \mathrm{~min}$ と し、1000 サイクルまでの所定のサイクル数ごとに取り出し、 SATによって超音波接合部の剥離状態について観察した。 


\section{3. 結果と考察}

3.1 半導体チップ上への $\mathrm{Al} / \mathrm{Cu}$ リード端子の直接超音波接 合の検討

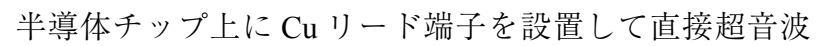
接合した場合、 $\mathrm{Cu}$ リード端子と比較して、半導体チップの 最表面に存在する $\mathrm{Al}$ 電極（厚さ数 $\mu \mathrm{m}$ ）の方が柔らかいた め、 $\mathrm{Al}$ 電極が完全に除去され、 $\mathrm{Cu}$ リード端子が半導体チッ プに直接接触し、チップにダメージが加わる。結果として、 Fig.5に示した超音波接合後の断面写真のように、半導体 チップにクラックが発生する。そこで、本評価では、半導 体チップヘのダメージを抑制するために緩衝層である $\mathrm{Al}$ 層 を $\mathrm{Cu}$ リード端子に圧接接合させた $\mathrm{Al} / \mathrm{Cu}$ クラッド材をリー

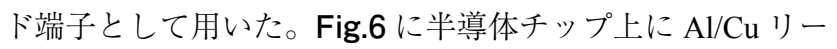
ド端子を超音波接合したサンプル（接合条件 周波数：40 $\mathrm{kHz}$ 、振幅：14.5 $\mu \mathrm{m}$ 、荷重：120 N、接合時間 $0.2 \mathrm{~s}$ ）の断

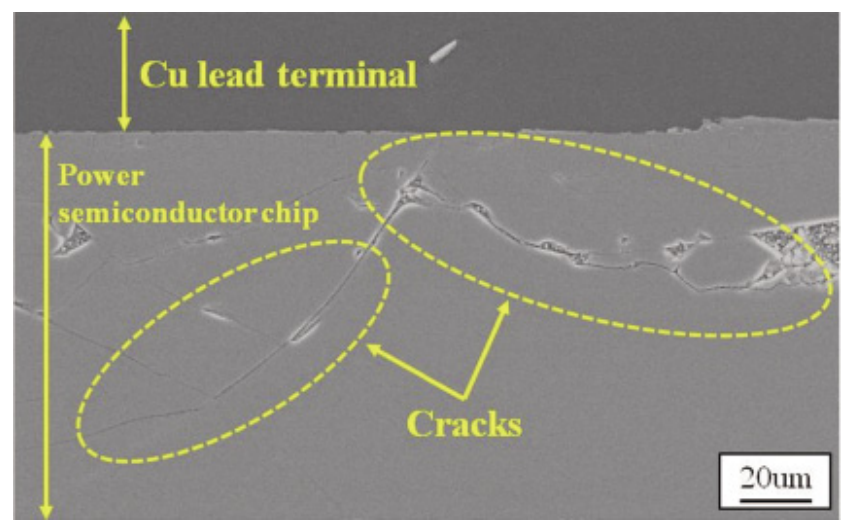

Fig.5 Cross section of bonding interface between $\mathrm{Cu}$ lead terminal and power semiconductor chip.

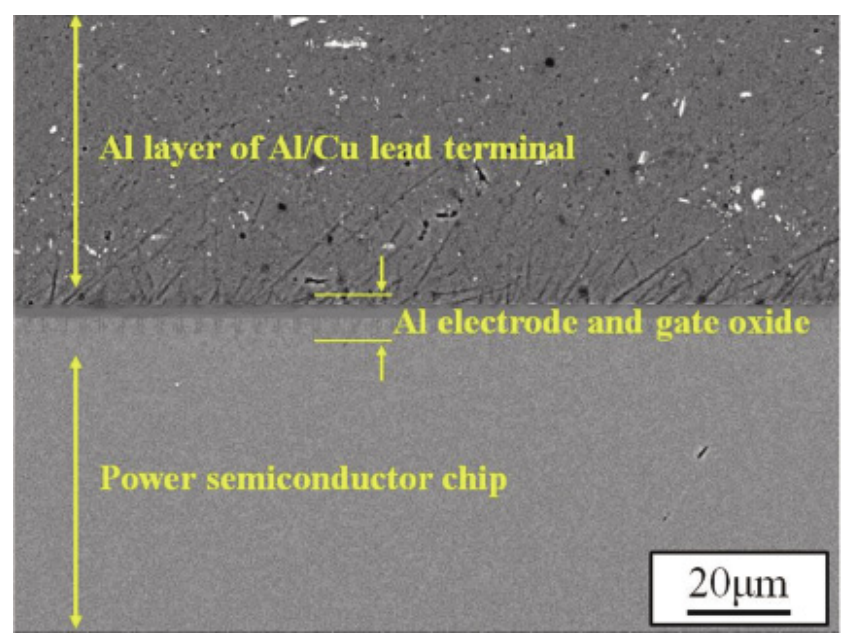

Fig.6 Cross section of bonding interface between $\mathrm{Al} / \mathrm{Cu}$ lead terminal and power semiconductor chip.
面写真を示す。Fig.6より、 $\mathrm{Al} / \mathrm{Cu}$ クラッド材をリード端子 として用いることで、 $\mathrm{Al}$ 電極を完全に除去することなく超 音波接合可能でありることを確認した。また、クラックな どの半導体チップへのダメージも見られなかった。

\section{2 超音波接合におけるチップの傾きの影響}

はんだ材を用いた半導体チップのダイボンドにおいて、 はんだ厚さのばらつきは Ni ボール入りはんだの使用などに よって、ある程度は抑制できるものの、完全にはんだ厚さ を均一にすることは難しい。つまり、リード端子を半導体 チップ上に直接超音波接合する際、半導体チップ傾きによ る影響を考慮する必要がある。そこで、半導体チップ上へ の $\mathrm{Al} / \mathrm{Cu}$ リード端子の直接超音波接合において、ダイボン ド後の半導体チップ傾きが与える影響について評価を行っ た。ダイボンド後に半導体チップが傾いていると、超音波

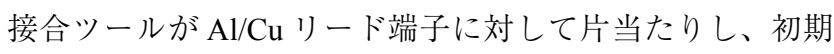

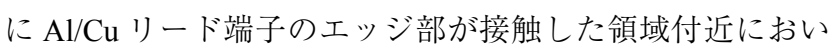
て過剩な荷重が加わることによる半導体チップへのダメー

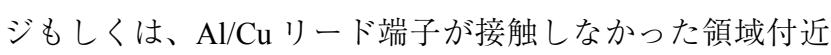
において所定の荷重が加わらないことによる未接合領域の 発生といった問題が生じる。Fig.7に各半導体チップ傾き における超音波接合後の $\mathrm{Al} / \mathrm{Cu}$ リード端子の表面観察結果 および、SATによる接合状態の観察結果を示す。Fig.7の

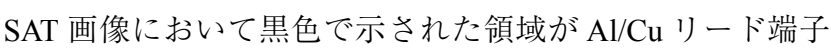
と半導体チップとの接合領域である。この画像を二值化し、 接合領域の画素数より接合面積を概算した。Fig.7(a)の端 子表面の写真より、半導体チップ傾きが小さい場合（チッ プ傾き： $12.0 \mu \mathrm{m}) 、 \mathrm{Al} / \mathrm{Cu}$ リード端子の表面に均一な圧痕 が形成されていた。また、SAT 観察結果より、超音波接合
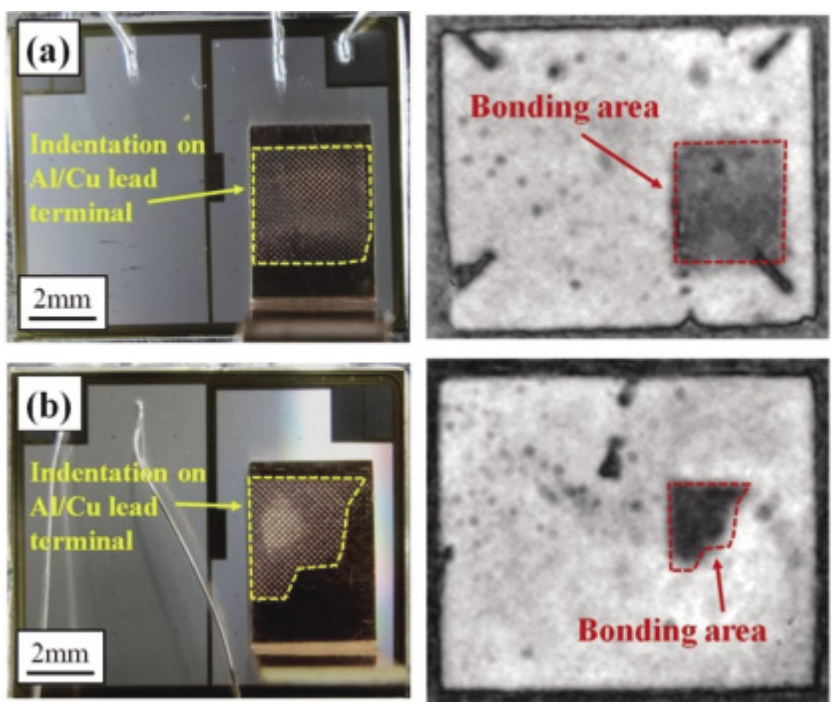

Fig.7 Photo images of $\mathrm{Al} / \mathrm{Cu}$ lead terminal and, SAT images of bonding interface after ultrasonic bonding. (a) Small chip tilt: $12.0 \mu \mathrm{m}$, (b) Large chip tilt: $98.8 \mu \mathrm{m}$. 


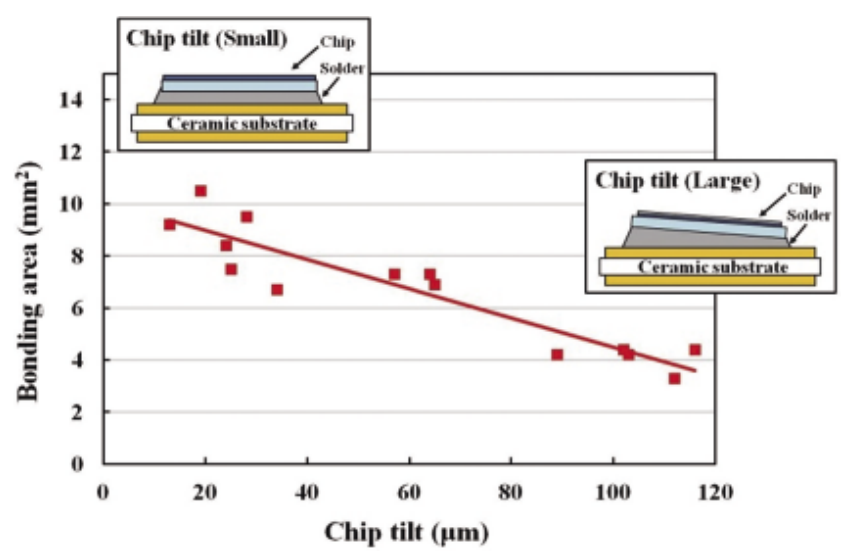

Fig.8 Effect of chip tilt on bonding area.

後の $\mathrm{Al} / \mathrm{Cu}$ リード端子表面の圧痕形状と同様な形状の接合 領域が得られていることを確認した。一方で、チップ傾き

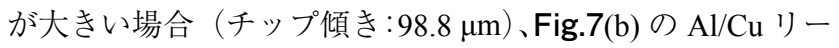
ド端子表面の写真より、 $\mathrm{Al} / \mathrm{Cu}$ リード端子の表面圧痕は、 左上に偏った形状で形成されており、また、チップ傾きの 小さいサンプルと比較して接合面積も減少していることが 分かる。Fig.8に半導体チップ傾きと接合面積の関係を示す (接合条件 周波数 : $30 \mathrm{kHz}$ 、振幅 : $15.2 \mu \mathrm{m}$ 、荷重 : $100 \mathrm{~N}$ 、 接合時間 $0.2 \mathrm{~s}$ )。チップ傾きの増加に伴って接合面積が減 少する傾向が見られた。これら接合面積の減少は、超音波

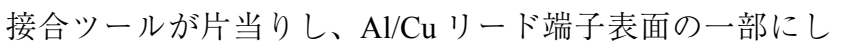
か規定の荷重が加わらなかったためと考えられる。

\section{3 バンプ $\mathrm{Al} / \mathrm{Cu}$ リード端子の適用検討}

半導体チップ傾きによって接合面積が減少し、必要な接 合面積を確保できなかった場合、通電時に過㮃な発熱が懸 念される。想定以上の熱が発生した場合、接合部における 熱歪みも大きくなるため $\mathrm{Al} / \mathrm{Cu}$ リード端子接合部の信頼性 低下の原因となる。そこで、半導体チップ傾きによらず接 合面積の確保が可能なリード端子形状を検討した。Fig.3(b)

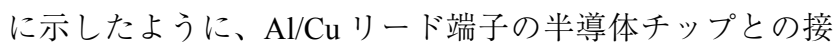
合面である $\mathrm{Al}$ 層側に $\phi 100 \mu \mathrm{m}$ 、高さ $0.1 \mathrm{~mm}$ のバンプを接 合面の中心に 1 点、四隅に各 1 点ずつの計 5 点形成した。 このリード端子形状であれば、端子先端のバンプが優先的 に潰れて接合されていくため、半導体チップに傾きによる 接合面積の減少を抑制できると考えられる。Fig.9に各半導

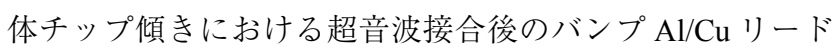
端子の表面観察結果および、SATによる接合状態の観察結 果を示す（接合条件 周波数 : $30 \mathrm{kHz}$ 、振幅 : $15.2 \mu \mathrm{m}$ 、荷 重: $100 \mathrm{~N}$ 、接合時間 $0.2 \mathrm{~s}$ )。Fig.9(a)、(b) のバンプ $\mathrm{Al} / \mathrm{Cu} リ ー$ ド端子表面の写真より、半導体チップ傾きが小さいサンプ ル（チップ傾き: $13.0 \mu \mathrm{m})$ と大きいサンプル（チップ傾き：

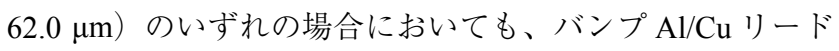
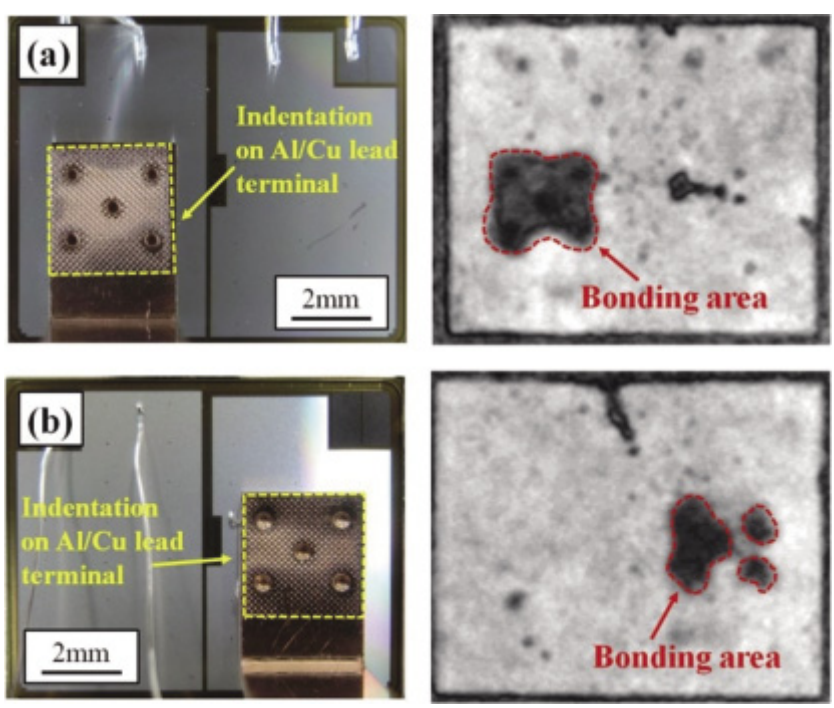

Fig.9 Photo images of bumped $\mathrm{Al} / \mathrm{Cu}$ lead terminal and, SAT images of bonding interface after ultrasonic bonding. (a) Small chip tilt: 13.0 $\mu \mathrm{m}$, (b) Large chip tilt: $62.0 \mu \mathrm{m}$.

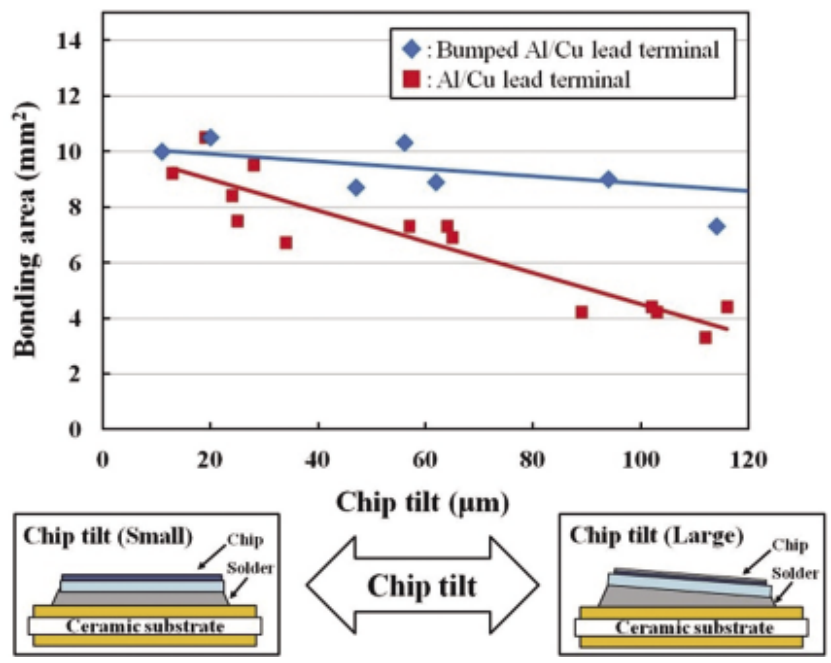

Fig.10 Effect of chip tilt on bonding area.

端子の表面に均一な圧痕が形成されていた。また、Fig.9(a) の SAT 観察結果より、バンプ $\mathrm{Al} / \mathrm{Cu}$ リード端子のバンプ位 置 (5 ケ所) を中心に接合領域が広がっていることが分かる。 また、Fig.9(b) のSAT 観察結果より、チップ傾きの大きい サンプル（チップ傾き： $62 \mu \mathrm{m} ）$ においても、接合面積が 減少しているものの、バンプ位置（5ケ所）を中心に接合 領域が得られることが分かった。Fig.10にバンプを形成し

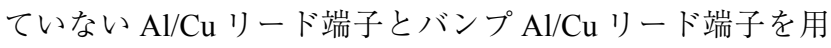
いた半導体チップ上の超音波接合において、半導体チップ 傾きと接合面積の関係を示す（接合条件 周波数： $30 \mathrm{kHz}$ 、 


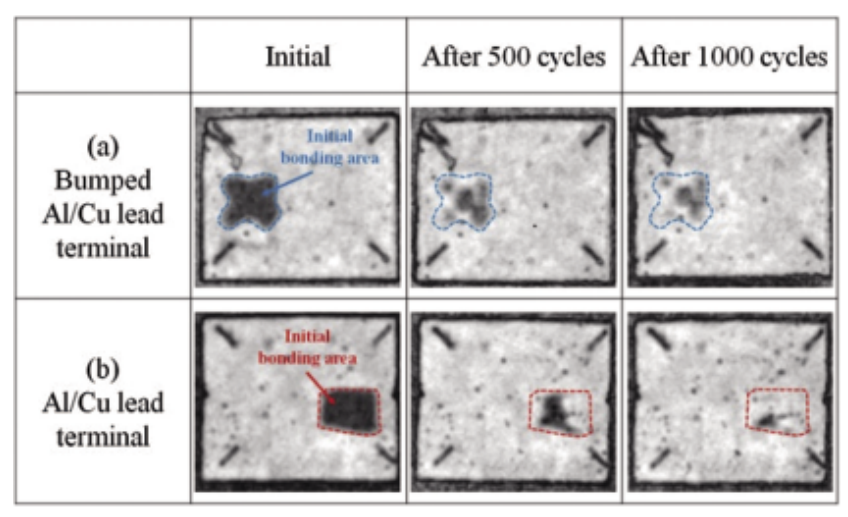

Fig.11 SAT image of bonding interface after thermal cycling test ( $45 \sim 150^{\circ} \mathrm{C}$ ). (a) Bumped $\mathrm{Al} / \mathrm{Cu}$ lead terminal, (b) $\mathrm{Al} / \mathrm{Cu}$ lead terminal.

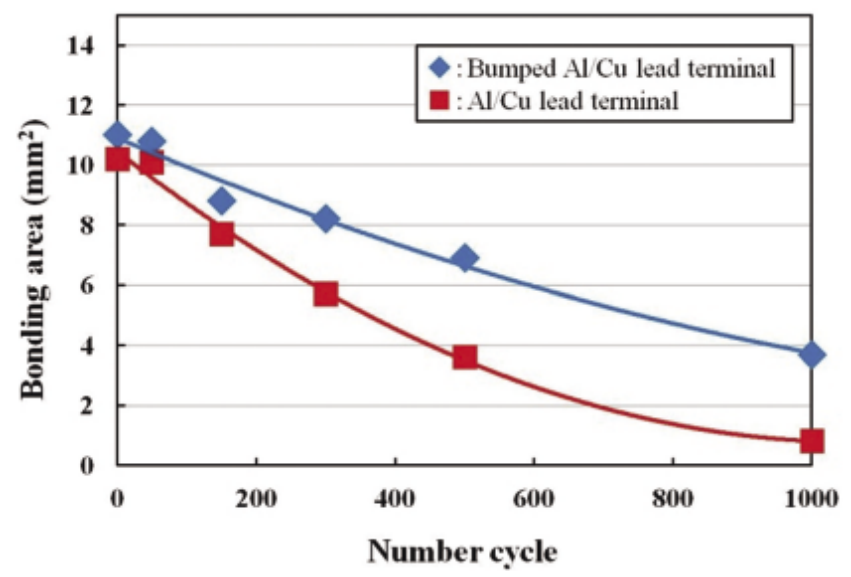

Fig.12 Effect of bumps on changes of bonding area through $-45 / 150^{\circ} \mathrm{C}$ thermal cycling test.

振幅： $15.2 \mu \mathrm{m}$ 、荷重：100 N、接合時間 $0.2 \mathrm{~s}$ )。いずれの リード端子を超音波接合した場合も、チップ傾きの増加に 伴って接合面積が減少する傾向が見られた。しかしながら、

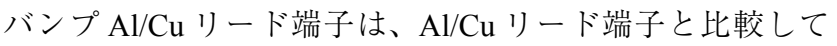
接合面積の減少傾向が小さく、バンプ形成によって半導体 チップ傾きによる接合面積減少の抑制効果が確認できた。 これは、リード端子先端のバンプが優先的に潰れて接合さ れていくため、半導体チップ傾きによらず接触状態が安定 するためであると考えられる。

\section{4 温度サイクル試験}

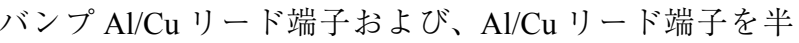
導体チップ上に直接超音波接合したサンプルについて、温 度サイクル試験（ $-45^{\circ} \mathrm{C} \sim 150^{\circ} \mathrm{C} 、 20 \mathrm{~min} / 20 \mathrm{~min} ）$ を実施 した（接合条件 周波数： $30 \mathrm{kHz}$ 、振幅：15.2 $\mu \mathrm{m}$ 、荷重： $100 \mathrm{~N}$ 、接合時間 $0.2 \mathrm{~s}$ )。0 サイクル（初期）から 1000 サ
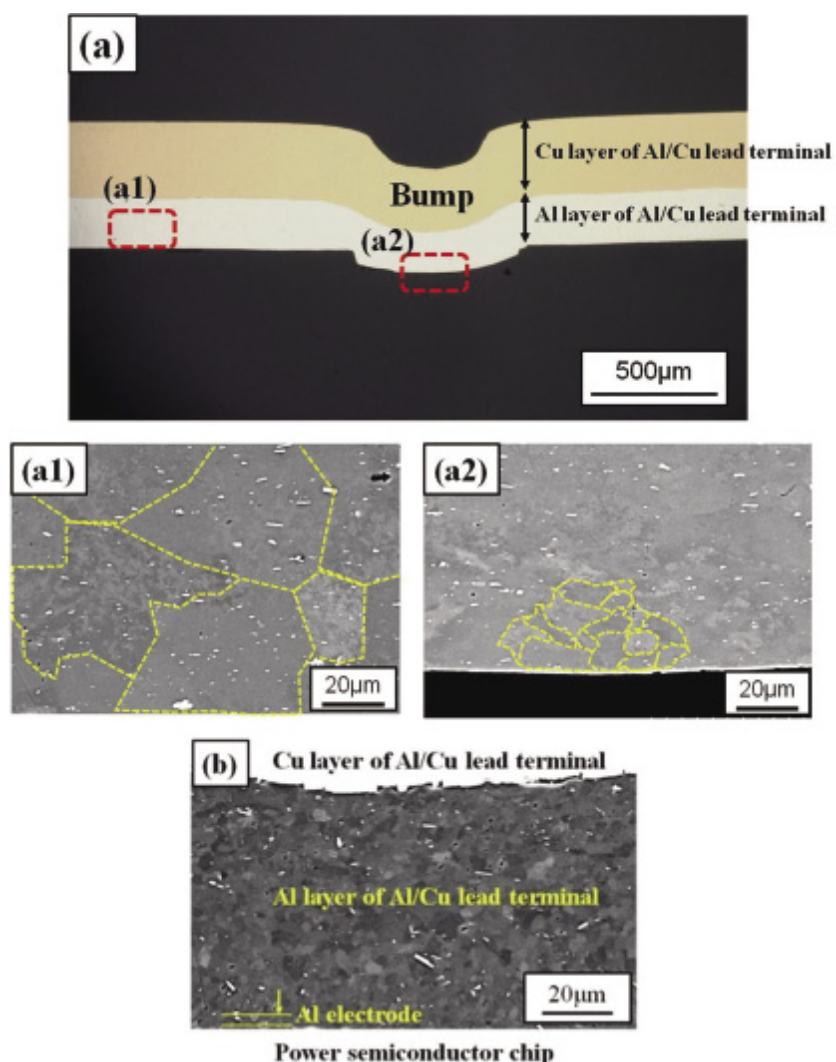

Fig.13 Cross section image of bonding interface with bumped $\mathrm{Al} / \mathrm{Cu}$ lead terminal.

(a) before bonding, (b) after bonding

イクルまでの所定のサイクル数での SAT 画像を Fig.11に、 サイクル数と接合面積の関係を Fig.12 に示す。 $\mathrm{Al} / \mathrm{Cu}$ リー ド端子は、サイクル数の増加とともに両端から中央部に向 かって剥離が進展していき、500 サイクル時点で接合面積 は、初期の半分以下になり、1000 サイクル後には初期の 接合面積の $8.4 \%$ にまで減少した。一方で、バンプ $\mathrm{Al} / \mathrm{Cu}$ リード端子は、バンプ直下の領域は剥離することなく接合 状態を維持し、1000 サイクル後でも接合面積が $34.5 \%$ であ り、 $\mathrm{Al} / \mathrm{Cu}$ リード端子と比較して高い温度サイクル信頼性

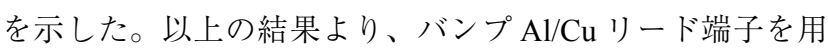
いることで、温度サイクル寿命の改善効果を実証できた。

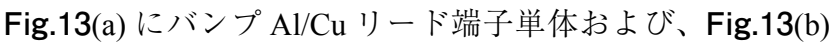
に超音波接合した後の断面観察結果を示す。Fig.13(a1) お

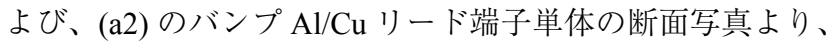
プレス加工によってバンプを形成した箇所の $\mathrm{Al}$ の結晶粒 は、その他の場所の $\mathrm{Al}$ の結晶粒と比較して細かくなってい

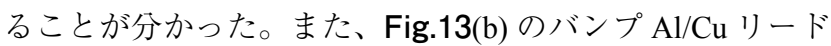
端子を用いて超音波接合した後の断面写真より、 $\mathrm{Al}$ 電極と

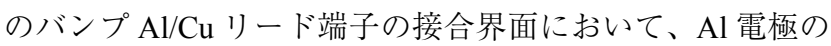
結晶サイズと同等の微細な結晶粒が観察された。温度サイ 
クルによる結晶粒の粗大化が、接合層にクラックを形成し、 信頼性低下の原因になるといわれている ${ }^{5)}$ 。つまり、バン プ形成部の $\mathrm{Al}$ 層と $\mathrm{Al}$ 電極の微細な結晶同士の超音波接合 により、微細な結晶粒を有する接合界面が得られ、結果と して、温度サイクル信頼性が向上したと思われる。

\section{4. まとめ}

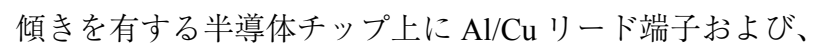
バンプ $\mathrm{Al} / \mathrm{Cu}$ リード端子を直接超音波接合し、半導体チッ プ傾きの影響について検証し、それらの信頼性について検 討した結果、以下の知見が得られた。

1) $\mathrm{Al} / \mathrm{Cu}$ リード端子において、チップ傾きが存在すると、 超音波接合ツールの片当たりによって接合面積が減少す ることが分かった。

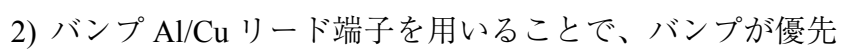
的に潰れて接合され、チップ傾き（数 $\mu \mathrm{m}$ ～約 $200 \mu \mathrm{m}$ ) による接合面積の減少を抑制する効果が得られた。

3) 温度サイクル試験 $\left(-45^{\circ} \mathrm{C} \sim 150^{\circ} \mathrm{C}\right)$ の結果、バンプ

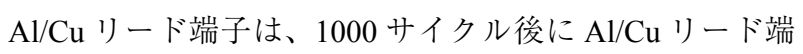
子と比較して約 4 倍の接合面積を維持し、温度サイクル 寿命の改善効果を実証できた。

\section{参考文献}

1) 木戸和優、百瀬文彦、西村芳孝、後藤友彰、”IGBT モジュー ル用超音波接合技術の開発（第二報）”、第 17 回エレクトロ ニクスにおけるマイクロ接合・実装技術シンポジウム論文集、 17 (2011) 197-200.

2) Bryan Ong, Mohd Helmy, Shirley Chuah, "Heavy Al Ribbon Interconnect: An Alternative Solution for Hybrid Power Packaging", Proc. IMAPS International Conference and Exhibition on High Temperature Electronics, HiTEC 2004, Long Beach, CA; United States; November 14-18, 2004, p1-10.

3) K. Ozaki, T. Kurosu, J. Onuki, "Development of Damage Free Thick Al-Cu Wire Bonding Process and Reliability of the Wire Bonds", The Electrochemical Society of Japan, 82(2) (2014) 100-103.

4) 米田裕、坂元創一、荒谷修三、菊池正雄、柳本辰則、茂永隆、” 超音波接合に扔けるインサート材が接合性に与える影響”、第 20 回エレクトロニクスに扔けるマイクロ接合・実装技術シン ポジウム論文集、 20 (2014) 75-78.

5) T. Saito, Y. Nishimura, K. Kido, F. Momose, E. Mochizuki, Y. Takahashi, "New assembly technologies for Tjmax $=175{ }^{\circ} \mathrm{C}$ continuous operation guaranty of IGBT module", Proc. PCIM Europe 2013, Nuremberg; Germany; May 14-16, 2013, p455-461. 